\title{
Apocrine Hidrocystoma
}

National Cancer Institute

\section{Source}

National Cancer Institute. Apocrine Hidrocystoma. NCI Thesaurus. Code C43342.

A slow-growing, usually solitary, dome-shaped benign sweat gland adenoma, most

frequently located on the eyelid. It is characterized by a cystic proliferation of apocrine glands. Surgical excision is curative. 